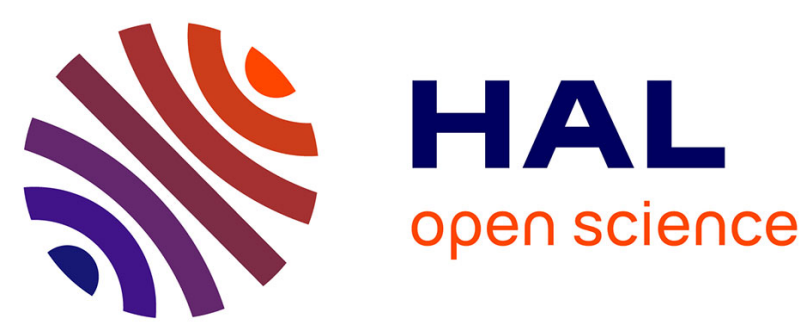

\title{
Laser Beam Direct Energy Deposition of graded austenitic-to-martensitic steel junctions compared to dissimilar Electron Beam welding
}

Flore Villaret, Xavier Boulnat, Pascal Aubry, Yasuhide Yano, Satoshi

Ohtsuka, Damien Fabrègue, Yann Decarlan

\section{To cite this version:}

Flore Villaret, Xavier Boulnat, Pascal Aubry, Yasuhide Yano, Satoshi Ohtsuka, et al.. Laser Beam Direct Energy Deposition of graded austenitic-to-martensitic steel junctions compared to dissimilar Electron Beam welding. Materials Science and Engineering: A, 2021, 824, pp.10.1016/j.msea.2021.141794. 10.1016/j.msea.2021.141794 . cea-03330867

\section{HAL Id: cea-03330867 https://hal-cea.archives-ouvertes.fr/cea-03330867}

Submitted on 1 Sep 2021

HAL is a multi-disciplinary open access archive for the deposit and dissemination of scientific research documents, whether they are published or not. The documents may come from teaching and research institutions in France or abroad, or from public or private research centers.
L'archive ouverte pluridisciplinaire HAL, est destinée au dépôt et à la diffusion de documents scientifiques de niveau recherche, publiés ou non, émanant des établissements d'enseignement et de recherche français ou étrangers, des laboratoires publics ou privés.

\section{(1) (1) $\$$}

Distributed under a Creative Commons Attribution - NonCommercial - NoDerivatives 44.0 


\title{
Laser Beam Direct Energy Deposition of graded austenitic- to-martensitic steel junctions compared to dissimilar Electron Beam welding
}

\author{
Flore Villareta ${ }^{a} 1^{\star}$, Xavier Boulnat ${ }^{b}$, Pascal Aubryc, Yasuhide Yano ${ }^{d}$, Satoshi Ohtsuka ${ }^{d}$, Damien Fabrègue ${ }^{b}$, \\ Yann de Carlan ${ }^{\mathrm{a}}$ \\ a Université Paris-Saclay, CEA, Service de Recherches Métallurgiques Appliquées, 91191, Gif-sur-Yvette, \\ France \\ b Université de Lyon, INSA de Lyon, MATEIS CNRS UMR 5510, F-69621 Villeurbanne, France \\ c Université Paris-Saclay, CEA, Service d'Études Analytiques et de Réactivité des Surfaces, 91191, Gif- \\ sur-Yvette, France \\ d Japan Atomic Energy Agency, 4002 Narita-cho, Oarai-machi, Ibaraki, 311-1393, Japan \\ ${ }^{*}$ Corresponding author, flore.villaret@edf.fr \\ ${ }^{1}$ Present address: EDF R\&D, MMC C24, Les Renardières, Moret-sur-Loing, F-77250 France
}

\begin{abstract}
This article presents the Laser Beam Direct Energy Deposition (DED-LB) process as a method to build a graded austenitic-to-martensitic steel junction.

Builds were obtained by varying the ratio of the two powders during DED-LB processing. Samples with gradual transitions were successfully obtained using a high dilution rate from one layer to the next. Long austenitic grains are observed on the $316 \mathrm{~L}$ side while martensitic grains are observed on the $\mathrm{Fe}-9 \mathrm{Cr}-1 \mathrm{Mo}$ side. In the transition zone the microstructure is mainly martensitic.

Characterisations performed after building and after a tempering heat treatment at $630^{\circ} \mathrm{C}$ for $8 \mathrm{~h}$ were compared to dissimilar Electron Beam (EB) welds. Before heat treatment the DED-LB graded area has high hardness (values of around $430 \mathrm{HV}$ ) due to fresh martensite formed during building. Tempering heat treatment reduces this hardness to $300 \mathrm{HV}$.
\end{abstract}

EDS measurements indicate that the chemical gradient between $316 \mathrm{~L}$ and Fe-9Cr-1Mo obtained by DEDLB is smoother than the chemical change obtained in EB welds. Microstructures in DED-LB are quite different from those obtained by EB welding. Hardness values in DED-LB samples and in welds are similar; the weld metal and the Fe-9Cr-1Mo heat-affected zone are relatively hard after welding because of fresh martensite, as found in the DED-LB transition zone; both are softened by tempering heat treatment.

Tensile tests show that DED-LB samples and EB welds have similar behaviour with failure in $316 \mathrm{~L}$ base metal at $20^{\circ} \mathrm{C}$ and $400^{\circ} \mathrm{C}$ and failure in $\mathrm{Fe}-9 \mathrm{Cr}-1 \mathrm{Mo}$ base metal at $550^{\circ} \mathrm{C}$. DED-LB samples have comparable mechanical properties to EB welds.

Keywords: gradient material, 316L, Fe-9Cr-1Mo, additive manufacturing, mechanical properties, electron beam welding

\section{INTRODUCTION}

Dissimilar junctions between austenitic stainless steels and martensitic steels are used in many applications. Examples of such heterogeneous junctions can be found in the nuclear industry where it is required to join $316 \mathrm{~L}$ and $\mathrm{Fe}-9 \mathrm{Cr}-1 \mathrm{Mo}$ steel parts. Usually, such junctions are performed by Tungsten Inert Gas (TIG) welding using an Inconel type filling metal. As explained by Pandey et al. [1], this process requires preheating before welding to avoid cold cracking and post-welding heat treatments to temper the 
martensite on Fe-9Cr-1Mo side. These heat treatments allow to obtain the required mechanical properties and especially a good toughness, as shown by Sireesha et al.[2].

Casalino et al. [3] demonstrate the feasibility of using hybrid laser/TIG welding as an alternative process to TIG welding. Yano et al. [4] also demonstrate the possibility of using an Electron Beam (EB) welding process to join a ferritic/martensitic steel with a 316L austenitic steel.

The use of chemical composition gradient materials obtained by powder metallurgy is another way to simplify this assembly step. Whether by "conventional" powder metallurgy or additive manufacturing, it is possible to consider the construction of a coupling sleeve which forms a connecting part between the two steels. Additive manufacturing is an attractive process as it opens up the design to new parts with complex geometry and specific functionality. The chemical composition of this connection will gradually change from $316 \mathrm{~L}$ to $\mathrm{Fe}-9 \mathrm{Cr}-1 \mathrm{Mo}$, allowing homogeneous welding at each end to simplify the assembly step. The coefficient of thermal expansion will change gradually through the graded part thereby reducing the mismatch between the two as shown by Sridharan et al. [5]. The reduction of this mismatch allows to reduce the residual stress trough the connector as observed by Woo et al. [6]. Zuback et al. [7] demonstrate also that the chemical gradient through the connector allows a gradual change in the carbon chemical potential, instead of step change, which can slow carbon diffusion from Fe-9Cr-1Mo to $316 \mathrm{~L}$ and extend the lifetime of the connection.

Usually, additive manufacturing techniques are used for their superior freedom for shape. In this work it is rather the possibility of changing the material and eventually mixing two alloys during the construction that is investigated. This technique has already been used by some authors such as Yan et al. [8] to build graded parts and join a variety of different materials successfully. Austenitic steel to ferritic/martensitic steel gradient materials have also been built by direct energy deposition and characterized by Sridharan et al. [5]. The present paper presents another practical case studying a 316L/Fe-9Cr-1Mo graded material obtained by DED-LB with a high dilution rate from one layer to the next affording a smooth gradient. The effect of a martensite tempering heat treatment at $630^{\circ} \mathrm{C}$ for $8 \mathrm{~h}$ is also investigated.

For comparison, a dissimilar Electron Beam (EB) weld was also performed to join the same two materials. This technique involves high energy density and narrow heat affected zone [9-11], hence minimizes distortion, which could be favourable for the welding of martensitic steels [12,13]. EB welding and DED-LB additive manufacturing have in particular close cooling rates, which makes the comparison interesting. In order to make a quantitative comparison, both as welded and heat treated samples were characterised in terms of microstructure and mechanical properties at room temperature, at $400^{\circ} \mathrm{C}$ and $550^{\circ} \mathrm{C}$.

\section{MATERIALS AND METHODS}

Graded material samples were obtained using $316 \mathrm{~L}$ and Fe-9Cr-1Mo pre-alloyed steel powders. Chemical composition and size distribution of powders used are given in Table 1. Samples were gas atomised powders with spherical particles.

\begin{tabular}{ccccccccccccc}
\hline $\begin{array}{c}\text { Composition } \\
\text { (wt\%) }\end{array}$ & supplier & $\mathrm{C}$ & $\mathrm{Cr}$ & $\mathrm{Ni}$ & $\mathrm{Mo}$ & $\mathrm{Mn}$ & $\mathrm{Si}$ & $\mathrm{N}$ & $\mathrm{D}_{10}(\mu \mathrm{m})$ & $\mathrm{D}_{50}(\mu \mathrm{m})$ & $\mathrm{D}_{90}(\mu \mathrm{m})$ \\
\hline $316 \mathrm{~L}$ & Erasteel & 0.016 & 17.7 & 12.6 & 2.33 & 0.29 & 0.58 & 0.08 & 57 & 78 & 108 \\
\hline Fe-9Cr-1Mo & Nanoval & 0.10 & 9.3 & 0.22 & 1.04 & 0.48 & 0.28 & 0.004 & 10 & 30 & 65 \\
\hline
\end{tabular}

Table 1: Chemical Composition, suppliers and size distribution of 316L and Fe-9Cr-1Mo powders.

Samples were obtained using the Laser Beam Direct Energy Deposition (DED-LB) process with two powder feeders enabling powder change during building (Figure 1). In this process, the powder is carried from the powder feeders to the constructed part by a carrying gas (argon here). It is possible to control the composition of the deposited layer by controlling the flow of each powder feeders. In this study, Fe-9Cr1 Mo was built over $316 \mathrm{~L}$ by changing directly from one powder to another without mixing powder in between. Parameters used for construction, listed in Table 2, were optimised for $316 \mathrm{~L}$ and kept constant 
during the building despite change of materials. Single tracks walls built with a back-and-forth strategy were used.

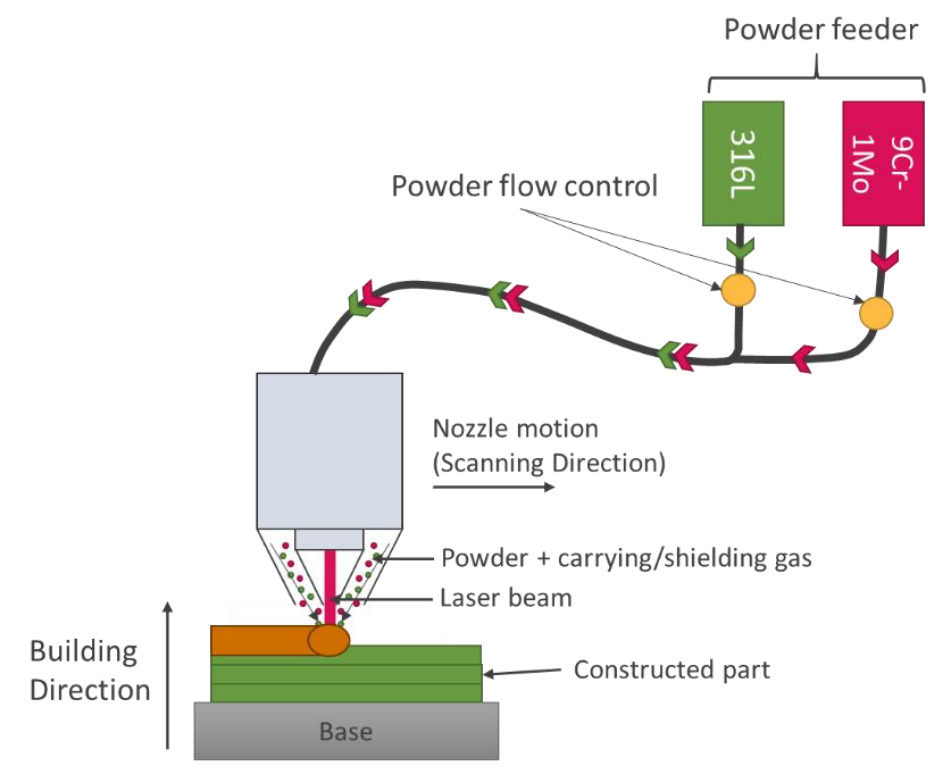

Figure 1: Operating scheme of the DED-LB process applied to the manufacture of gradient materials.

\begin{tabular}{cc}
\hline Setup & Optomec LENS 850 R \\
\hline Laser power (P) & $400 \mathrm{~W}$ \\
\hline Scanning speed $(\mathbf{v})$ & $5 \mathrm{~mm} / \mathrm{s}$ \\
\hline Layer height & $0.2 \mathrm{~mm}$ \\
\hline Carrying/shielding gas & Argon \\
\hline S16L powder feed rate & $1.4 \mathrm{~mm}$ \\
\hline Fe-9Cr-1Mo powder feed rate & $4 \mathrm{~g} / \mathrm{min}$ \\
\hline Energy density (P/v.D $\mathbf{D}_{\text {spot }}$ ) & $\left.2 \mathrm{~g} / \mathrm{min}_{\text {spot }}\right)$ \\
\hline
\end{tabular}

Table 2: DED-LB building parameters

Heat treatments for martensite tempering were performed at $630^{\circ} \mathrm{C}$ for $8 \mathrm{~h}$ on DED-LB samples. Electron Beam (EB) dissimilar welds were studied for comparison. EB welding conditions were: a focal point of $50 \mathrm{~mm}$, welding speed of 2,000 mm/min and an acceleration voltage of $60 \mathrm{kV}$. EB welding was performed on $5 \mathrm{~mm}$ thick plates with no nickel-base alloy filler. Post-weld heat treatment (PWHT) for all samples was performed at $630^{\circ} \mathrm{C}$ for $8 \mathrm{~h}$ also.

For optical metallographic analysis, samples were polished and successively electro-etched in 10 vol\% oxalic acid to reveal the austenitic microstructure and etched with Villela reagent to reveal the martensitic structure. Scanning electron microscopy (SEM), energy dispersive spectroscopy (EDS) and electron backscattered diffraction (EBSD) analyses were undertaken before the two-step etching. Two specimens extracted from the same DED-LB sample were used to study the effect of the tempering heat treatment. The same applies for EB welds. 
Vickers microhardness was measured at a load of $100 \mathrm{~g}$ for EB welds and $50 \mathrm{~g}$ for DED-LB samples. The space between two measurements was set to $100 \mu \mathrm{m}$ in the $X$ and $Y$ directions for DED-LB samples. This affords a hardness map across the interface between the two materials. However, as the welded area is much larger than the mixed area from additive manufacturing, this is why load used for measurements were different and the space between the two indentations was set to $200 \mu \mathrm{m}$ in X direction and $500 \mu \mathrm{m}$ in $Y$ direction for the EB welded samples.

After heat treatments, flat specimens with their graded area as well as with their weld located at the centre of the gauge section were used for tensile tests. Tensile properties were measured at three temperatures: $20^{\circ} \mathrm{C}, 400^{\circ} \mathrm{C}$ and $550^{\circ} \mathrm{C}$. Stress was applied across the weld and the gradient direction (parallel to the build direction for additive manufacturing) with a strain rate of $10^{-4} \mathrm{~s}^{-1}$. DED-LB samples were not surface machined before the test so presented a rough surface. Microtomography with a voxel size of $7.5 \mu \mathrm{m}$ was used to characterize the gauge length as previously described by [14]. The mean gauge section was used to plot tensile curves as the failure does not always occur in the thinnest part of thin specimens and the nature of the material also determines the failure area, depending on the test temperature.

\section{RESULTS: DED-LB GRADIENT MATERIAL}

\subsection{Microstructural STUDY}

Cross-sectional optical images of the $316 \mathrm{~L} / \mathrm{Fe}-9 \mathrm{Cr}-1 \mathrm{Mo}$ gradient sample after etching are presented in Figure 2 (c) and (d). A continuous and coherent interface between the two materials is seen. No large defects are observed in these samples with only a few pores. The 316L side is characterized by long elongated grains lying in build direction (BD) (Figure 2 (b)) while the Fe-9Cr-1Mo side is martensitic (Figure 2 (a) and (e)). Due to the parameters used the dilution rate from one layer to another is large at around $80 \%$ (measured by metallography). Even if, after the last $316 \mathrm{~L}$ layer, a $100 \% \mathrm{Fe}-9 \mathrm{Cr}-1 \mathrm{Mo}$ powder layer is deposited, the composition of that last deposited layer will be $80 \%$ of re-melted $316 \mathrm{~L}+20 \%$ of the new Fe-9Cr-1Mo, assuming complete mixing of the two alloys in the melted pool. For this reason, a smooth, graded area, not etched by any of the two etchants, is observed between $316 \mathrm{~L}$ and $\mathrm{Fe}-9 \mathrm{Cr}-1 \mathrm{Mo}$ in Figure 2 (c) and (d). The length of the unetched zone is around $1.5 \mathrm{~mm}$. 


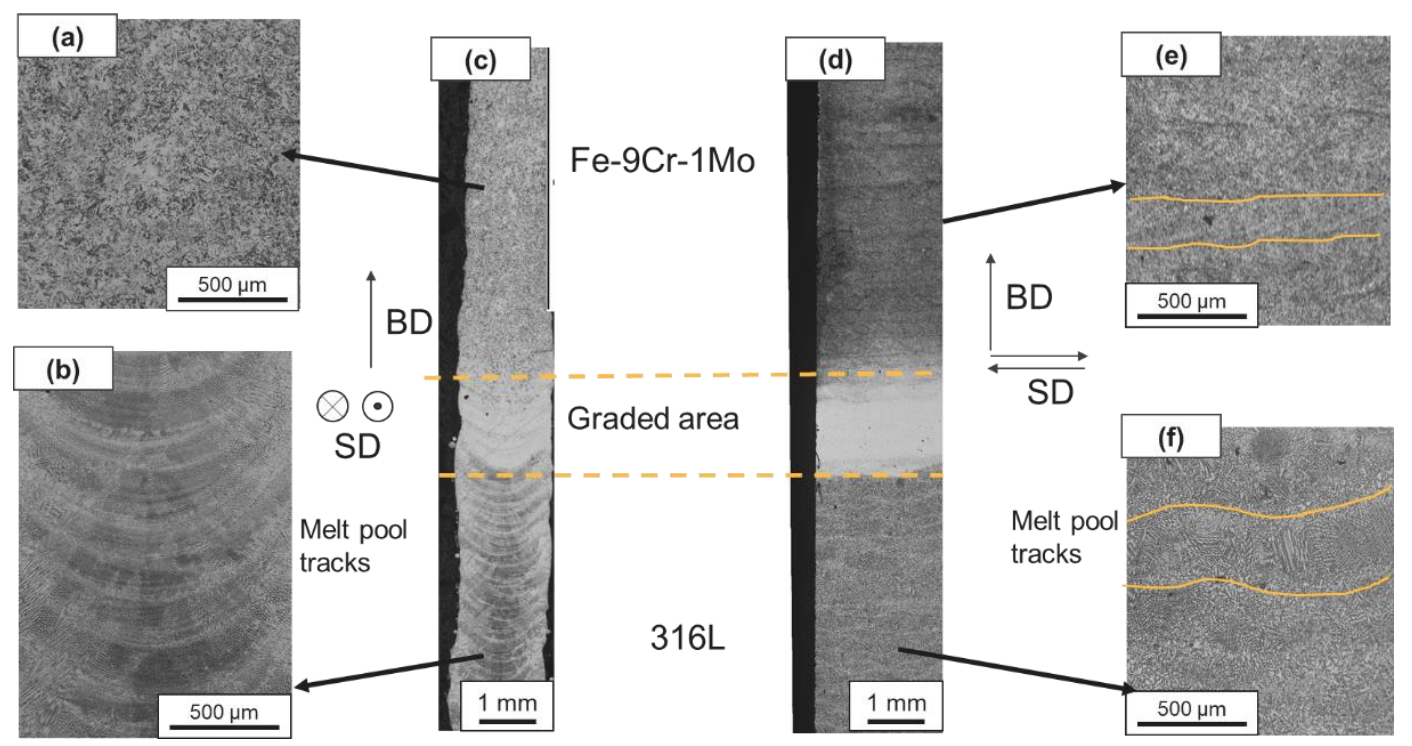

Figure 2: Optical micrographs after two-step etching of the as-built DED-LB sample (BD - build direction, SD - scanning direction). In the BD plane, perpendicular to the SD - details of (a) martensitic and (b) austenitic microstructures, (c) overview of the graded sample. In both the BD and SD planes - (d) overview of the graded sample and details of (e) the martensitic and (f) the austenitic microstructures.

Figure 3 and Figure 4 shows detail of the microstructure in the graded area. In Figure 3 (a) the 316L side is fully austenitic with large grains crossing several melt pools and elongated in the thermal gradient direction; the Fe-9Cr-1Mo side is fully martensitic. The EDS profile (Figure 3 (b)) shows that the chemical gradient is actually larger than the unetched area in figure 1. According to the forescattered electron (FSE) image and EDS profile (Figure 3 (a) and (b)), the first $300 \mu \mathrm{m}$ of the composition change is mainly austenitic whereafter the microstructure becomes mainly martensitic. The EBSD map (Figure 4 (a) and (b)) reveals a band of almost $100 \mu \mathrm{m}$ where the composition induces a mix between austenite and BCC phase. The morphology of some of these centred cubic regions suggests that they may be ferritic rather than martensitic. Distinguishing these two phases by EBSD is not easy and the BCC domains are relatively small, so it is not possible to separate them here. However, the intermediate compositions between 316 L and Fe-9Cr-1Mo pass through the three-phase $\mathrm{F}+\mathrm{M}+\mathrm{A}$ zone of the Schaeffler diagram, so it is possible to observe ferrite for these unusual compositions. Indeed, it is possible to maintain delta ferrite from the high temperature domain in additive manufacturing, due to the very high cooling rate undergone [15]. 


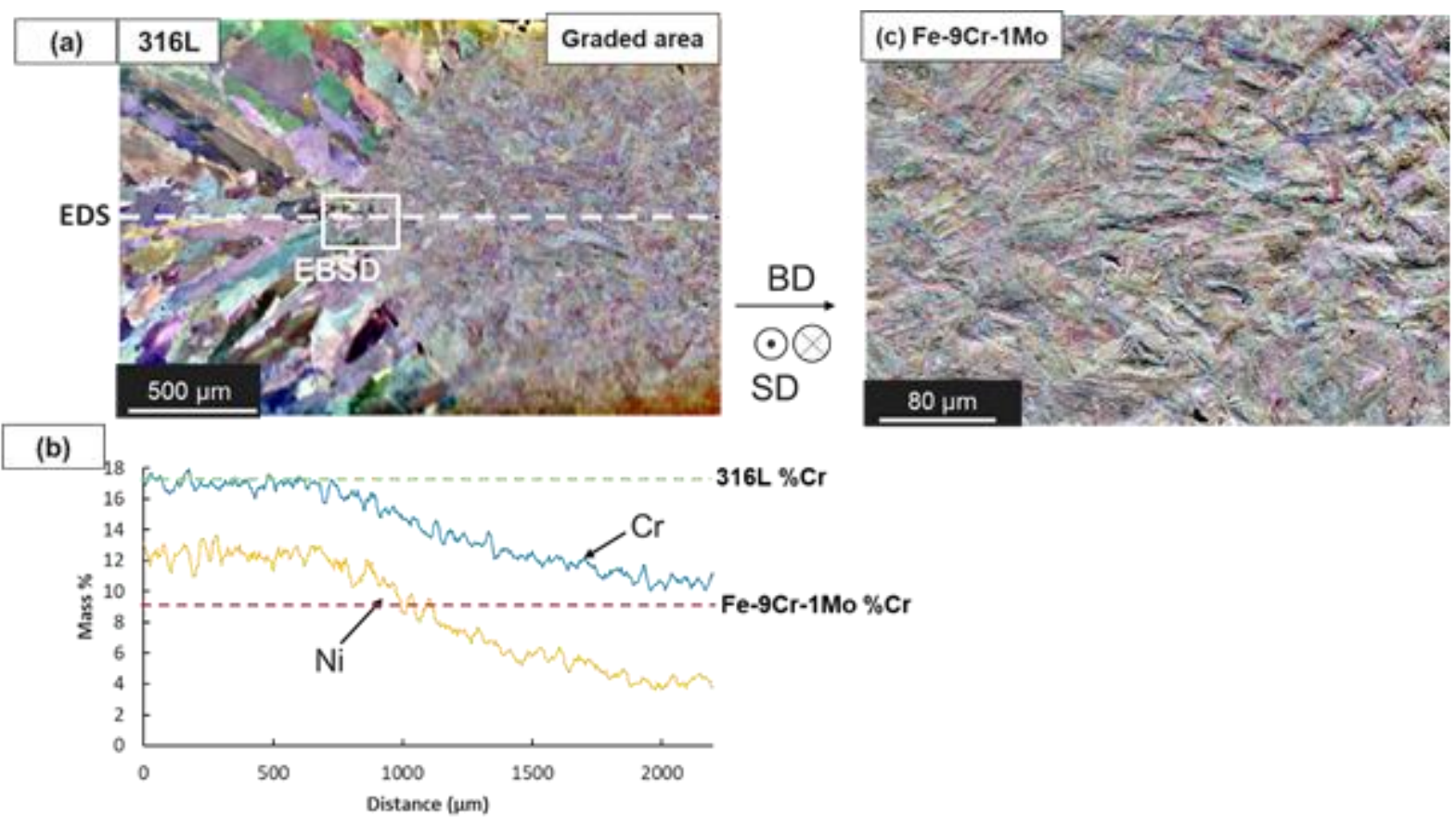

Figure 3: Analysis of the graded area: (a) forescattered electron (FSE) image overview of the microstructure and (b) corresponding EDS profile, (c) FSE image of the $\mathrm{Fe}-9 \mathrm{Cr}$ martensitic microstructure, far from the graded area. 


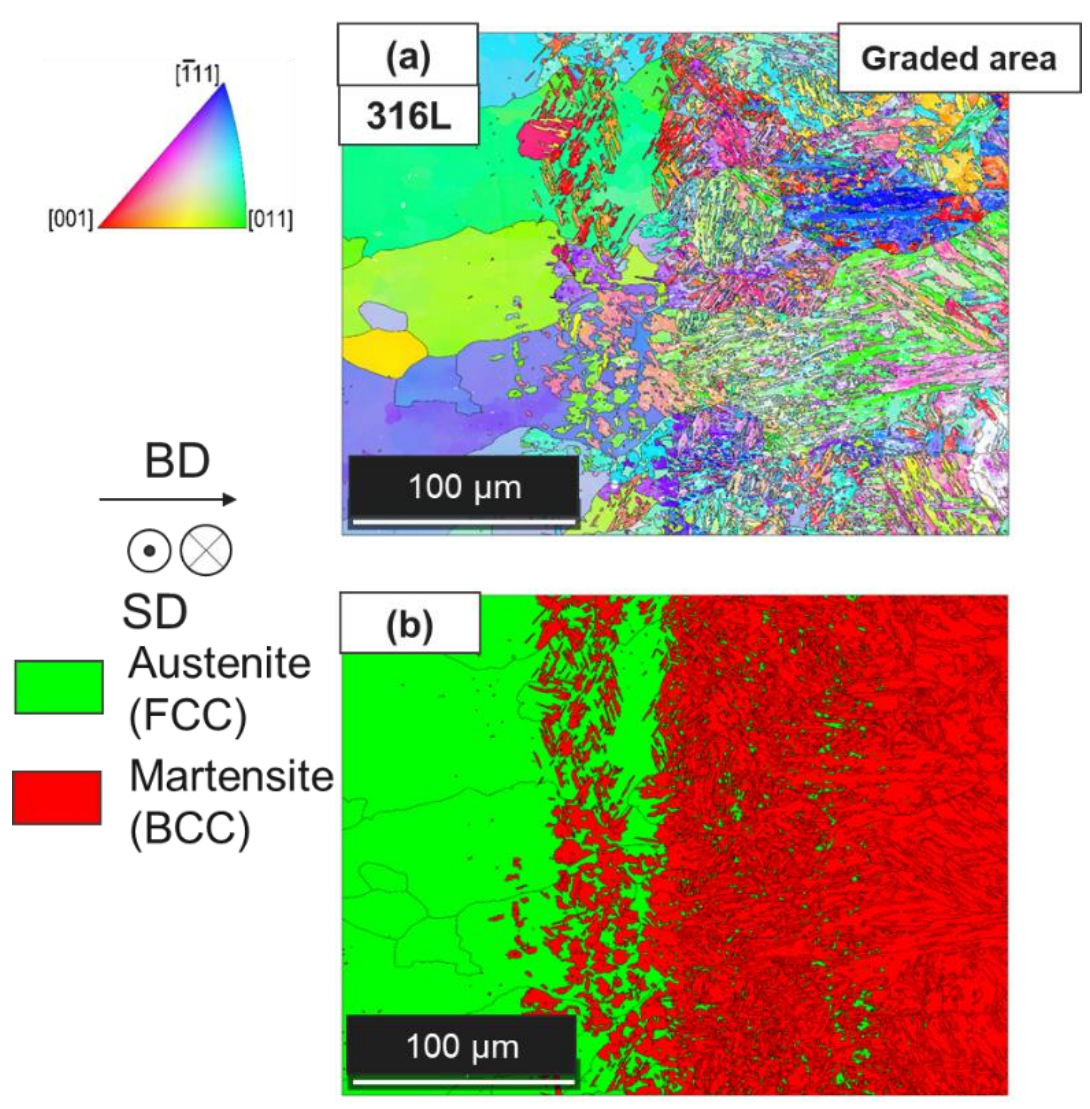

Figure 4: (a) EBSD IPF map and (b) EBSD phase map at the interface between 316L and graded area $(1$ pixel $=0.2 \mu \mathrm{m})$. IPF map is projected parallel to the build direction (BD), $10^{\circ}$ grain boundaries are shown in black. (color figure)

EBSD maps of the graded transition before and after heat treatment are presented in Figure 5. Away from the graded area the microstructure (SEM scale) of base metals is not modified by the heat treatment (Figure 5 (a) and (c)). $\mathrm{Cr}$ and $\mathrm{Ni}$ composition profiles are not modified by this tempering heat treatment as both temperature and duration are insufficient to allow homogenization of these elements [16]. In the transition area the formation of an austenitic phase on the martensitic side and a ferritic phase at the grain boundaries on the austenitic side are induced by heat treatment (Figure 5 (b) and (d)). The austenitic/martensitic mixed area seems to be wider after heat treatment and the austenite formed on the martensitic side is finer and more homogeneously distributed after heat treatment. These BCC domains are also finer after heat treatment, this suggest that this area could be austenitized partially during the heat treatment because its specific composition lowers $\mathrm{Ae}_{1}$ and $\mathrm{Ae}_{3}$ in comparison with $\mathrm{Fe}-9 \mathrm{Cr}-1 \mathrm{Mo}$. 

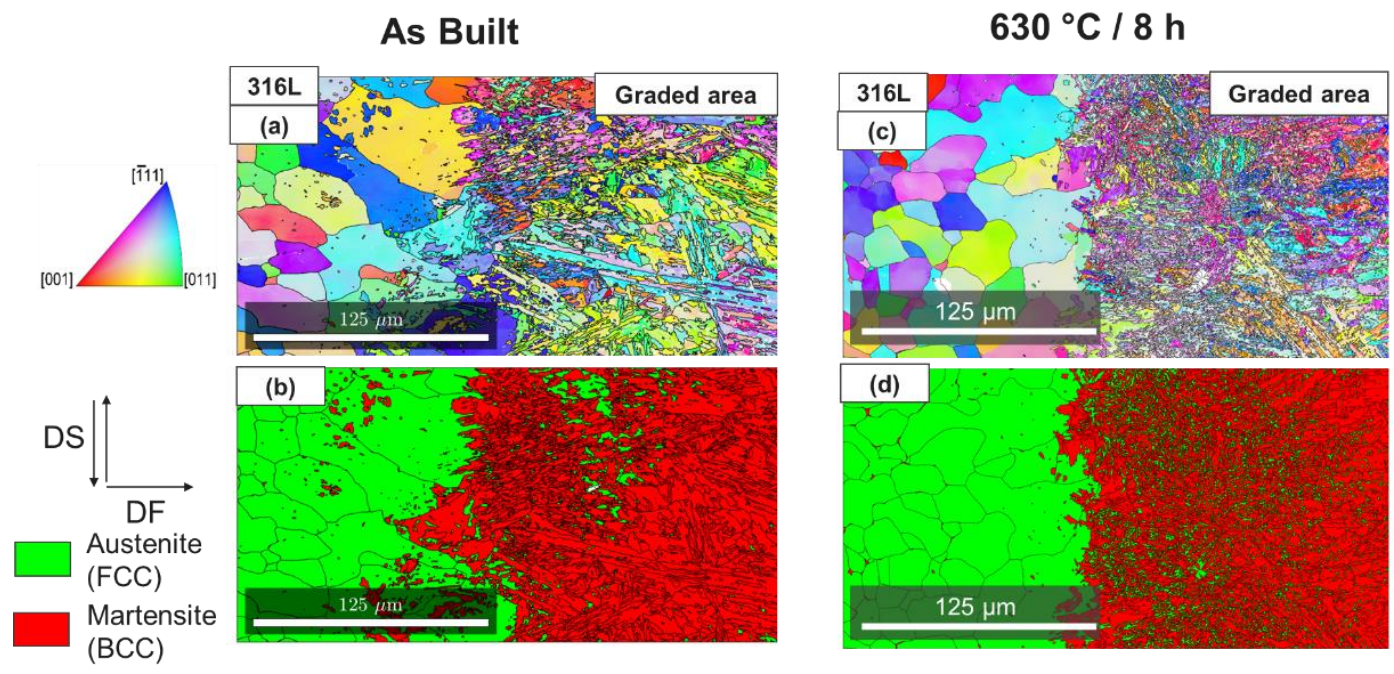

Figure 5: Effect of the tempering heat treatment on microstructure: (a) IPF map and (b) phase map as built and (c) IPF map and (d) phase map after $630^{\circ} \mathrm{C} / 8 \mathrm{~h}$ heat treatment. (color figure)

\subsection{Mechanical PROPERTIES}

\subsubsection{Hardness}

Changes in microstructure and alloy chemistry can lead to changes in mechanical properties. Vickers microhardness tests were performed to evaluate these changes across the junction and assess the results of heat treatment.

Figure 6 (b) and (c) show the microhardness maps obtained for DED-LB samples. Hardness on the 316L side is around $220 \mathrm{HV}$, the usual hardness found in as-built 316L DED-LB samples, for example by Ma et al. [17]. On the Fe-9Cr-1Mo side, the hardness is around $300 \mathrm{HV}$, a characteristic value of a slightly tempered martensite. In the graded area hardness rises progressively in the austenitic part. This smooth increase can be explained by the increase of carbon content coming from $\mathrm{Fe}-9 \mathrm{Cr}-1 \mathrm{Mo}$ steel. Hardness then rises sharply to $430 \mathrm{HV}$ when the microstructure becomes martensitic. Kim et al. [18] observed such hardness changes in direct energy deposited graded materials. These high hardness values could be due to chemical enrichment in alloying elements (such as $\mathrm{Ni}$ and $\mathrm{Cr}$ ) of the martensite from the $316 \mathrm{~L}$ in this area in compared to the Fe-9Cr-1Mo steel. The fine and dispersed austenite/BCC phase mix observed previously (Figure 5) also cause this hardness increase. After this peak, hardness progressively decreases until the Fe-9Cr-1Mo value is reached.

Applying a $630^{\circ} \mathrm{C} / 8 \mathrm{~h}$ tempering heat treatment to the graded parts reduces the hardness of the material globally (Figure 6 (a)). On 316L and Fe-9Cr-1Mo sides, hardness is reduced to 200 and $210 \mathrm{HV}$, respectively. Maximum hardness in the graded area is reduced to around $300 \mathrm{HV}$ (Figure 6 (c)). 


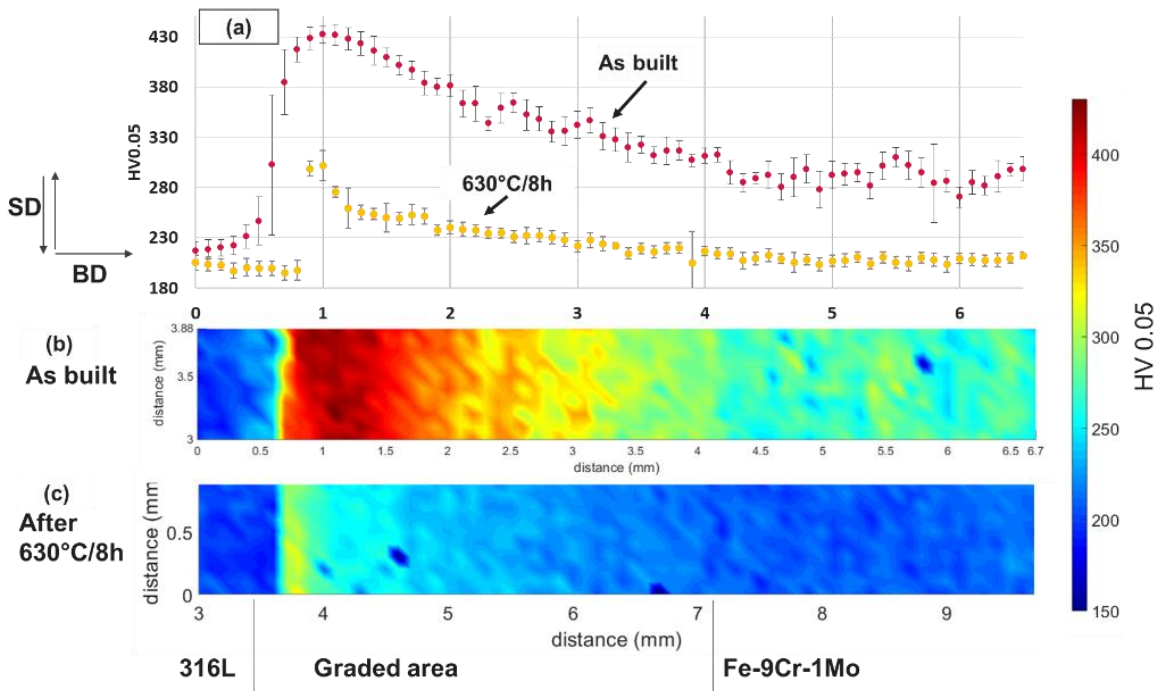

Figure 6: Microhardness measurements for DED-LB sample across the graded area: (a) mean hardness as a function of distance and corresponding hardness maps for the sample (a) as built and (b) after $630^{\circ} \mathrm{C} / 8 \mathrm{~h}$ heat treatment. (color figure)

\subsubsection{Tensile tests}

Tensile tests were performed after heat treatment on both on EB welds and DED-LB samples to evaluate mechanical properties of such junctions at a larger scale. Tensile test in EB base metal were also performed for comparison (Table 3). Flat specimens with their graded area as well as with their weld located at the centre of the gauge section were used for tensile tests. Tensile properties were measured at three temperatures: $20^{\circ} \mathrm{C}, 400^{\circ} \mathrm{C}$ and $550^{\circ} \mathrm{C}$. Stress was applied across the weld and the gradient direction (parallel to the build direction for additive manufacturing) with a strain rate of $10^{-4} \mathrm{~s}^{-1}$. Average gauge section determined by microtomography was used to plot the tensile stress-strain curves for DEDLB in Figure 7. Each tensile test was performed one time.

For all tests failure never occurred in the weld area nor in the graded area and the global tensile behaviors looked similar. At room temperature and at $400^{\circ} \mathrm{C}$ failure occurred in $316 \mathrm{~L}$ base metal both in EB welds and DED-LB samples.

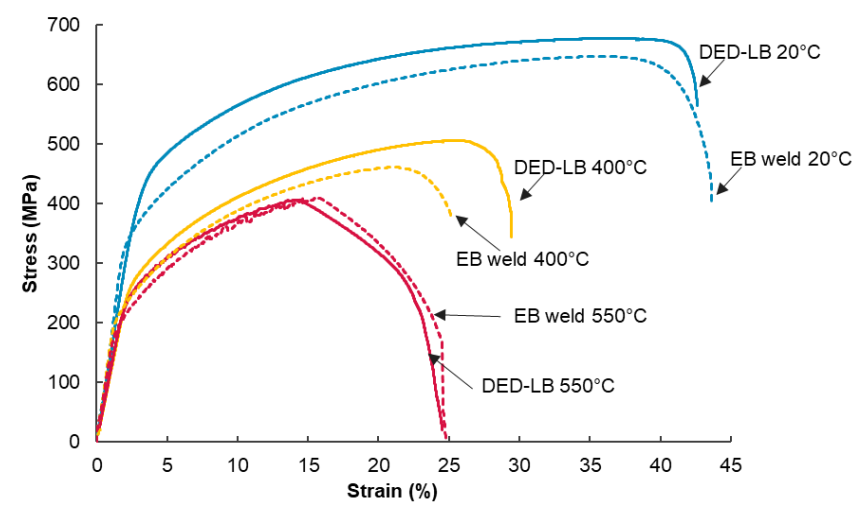

Figure 7: Tensile stress-strain curves for EB welds (dotted) and DED-LB transitions (solid) after $630^{\circ} \mathrm{C} / 8 \mathrm{~h}$ heat treatment at three test temperatures: $20^{\circ} \mathrm{C}$ (blue), $400^{\circ} \mathrm{C}$ (yellow) and $550^{\circ} \mathrm{C}$ (red).

For these temperatures, DED-LB samples showed yield strength and ultimate tensile strength slightly higher than EB welds, while the elongation was almost equal. At $550^{\circ} \mathrm{C}$ DED-LB samples and EB welds had similar properties with a failure in the Fe-9Cr-1Mo base metal. Such change in failure location with temperature is quite common in austenitic/martensitic welded assemblies, it has been observed for 
example by Yano et al. [4]. At room temperature and $400^{\circ} \mathrm{C}$ the yield strength and ultimate tensile strength of $316 \mathrm{~L}$ are usually lower than those of Fe-9Cr-1Mo so strain is mainly on the $316 \mathrm{~L}$ side (Table 3). At $550^{\circ} \mathrm{C} \mathrm{Fe}-9 \mathrm{Cr}-1 \mathrm{Mo}$ strengths were lower and closer to those of $316 \mathrm{~L}$; strain was homogeneous and failure occurred in Fe-9Cr-1Mo as it is less ductile.

\begin{tabular}{|c|c|c|c|c|c|c|c|c|c|}
\hline & \multicolumn{3}{|c|}{ YS (MPa) } & \multicolumn{3}{c|}{ UTS (MPa) } & \multicolumn{3}{c|}{ Total elongation \% } \\
\cline { 2 - 11 } & $\mathbf{2 0}^{\circ} \mathbf{C}$ & $\mathbf{4 0 0}^{\circ} \mathbf{C}$ & $\mathbf{5 5 0}^{\circ} \mathbf{C}$ & $\mathbf{2 0}^{\circ} \mathbf{C}$ & $\mathbf{4 0 0}^{\circ} \mathbf{C}$ & $\mathbf{5 5 0}^{\circ} \mathbf{C}$ & $\mathbf{2 0}^{\circ} \mathbf{C}$ & $\mathbf{4 0 0}^{\circ} \mathbf{C}$ & $\mathbf{5 5 0}^{\circ} \mathbf{C}$ \\
\hline $\mathbf{3 1 6 L}$ & 303 & 176 & 153 & 614 & 447 & 412 & 91.8 & 52,7 & 58.7 \\
\hline Fe-9Cr-1Mo & 562 & 453 & 397 & 698 & 558 & 419 & 25.9 & 18,5 & 24.8 \\
\hline DED-LB gradient & 420 & 346 & 287 & 610 & 478 & 357 & 23 & 18 & 23 \\
\hline EB weld & 330 & 204 & 189 & 647 & 459 & 402 & 43.6 & 19.1 & 24.7 \\
\hline
\end{tabular}

Table 3: DED-LB gradient and EB weld mechanical properties compared to base materials

\section{DISCUSSION: COMPARISON WITH EB WELD}

\subsection{Microstructure}

Microstructural characterization of EB welds was performed for comparison with DED-LB transitions. The starting materials have the same compositions but different forms. For DED-LB, steel powder was used, for EB welding laminated sheets were used. In EB welds, only the weld area is melted at the junction which means 316L and $\mathrm{Fe}-9 \mathrm{Cr}-1 \mathrm{Mo}$ sides away from the junction present typical equiaxed microstructure of laminated and heat treated sheets.

Figure 8 (a) presents an overview of the EB weld. This microstructure can be divided into several areas.

- On each side are the two base metals (BM), the austenitic side with some delta ferrite corresponding to $316 \mathrm{~L}$ stainless steel and the tempered martensitic microstructure of the Fe-9Cr1 Mo side.

- $\quad$ The welded metal in the middle is the area where the molten metal is mixed during welding.

- Two heat-affected zones (HAZ) surround the welded metal where the microstructure is changed by thermal input during welding but the metal is not melted.

Large EBSD maps and EDS scans presented in Figure 8 (b)-(e) demonstrate that weld metal is mainly martensitic with few austenitic areas. Weld metal composition obtained by EDS is $13 \% \mathrm{Cr}$ and $6 \% \mathrm{Ni}$ corresponding to a 50/50 mix (approx.) between 316 L and Fe-9Cr-1Mo.

At the interface between weld metal and 316L HAZ (Figure 8 (b)) martensitic and austenitic strips can be observed (indicated by an arrow). In the austenitic strips chemical composition is equivalent to $316 \mathrm{~L}$, while martensitic strips have a composition closer to the weld metal containing less $\mathrm{Ni}$ and $\mathrm{Cr}$ than $316 \mathrm{~L}$ (Figure 8 (c)). This unmixing at the weld metal/HAZ boundary is not usually observed in dissimilar welds, for example Abburi Venkata et al. [19] did not highlight any such phenomenon in their observations. The high speed used in EB welding can be responsible for instabilities of the melt pool during welding leading to unmixed areas after cooling. The weld metal/Fe-9Cr-1Mo HAZ boundary (Figure 8 (d)) does not present similar austenitic and martensitic strips; segregations observed on the EDS profile (Figure 8 (e)) are not important enough to promote austenite formation. 


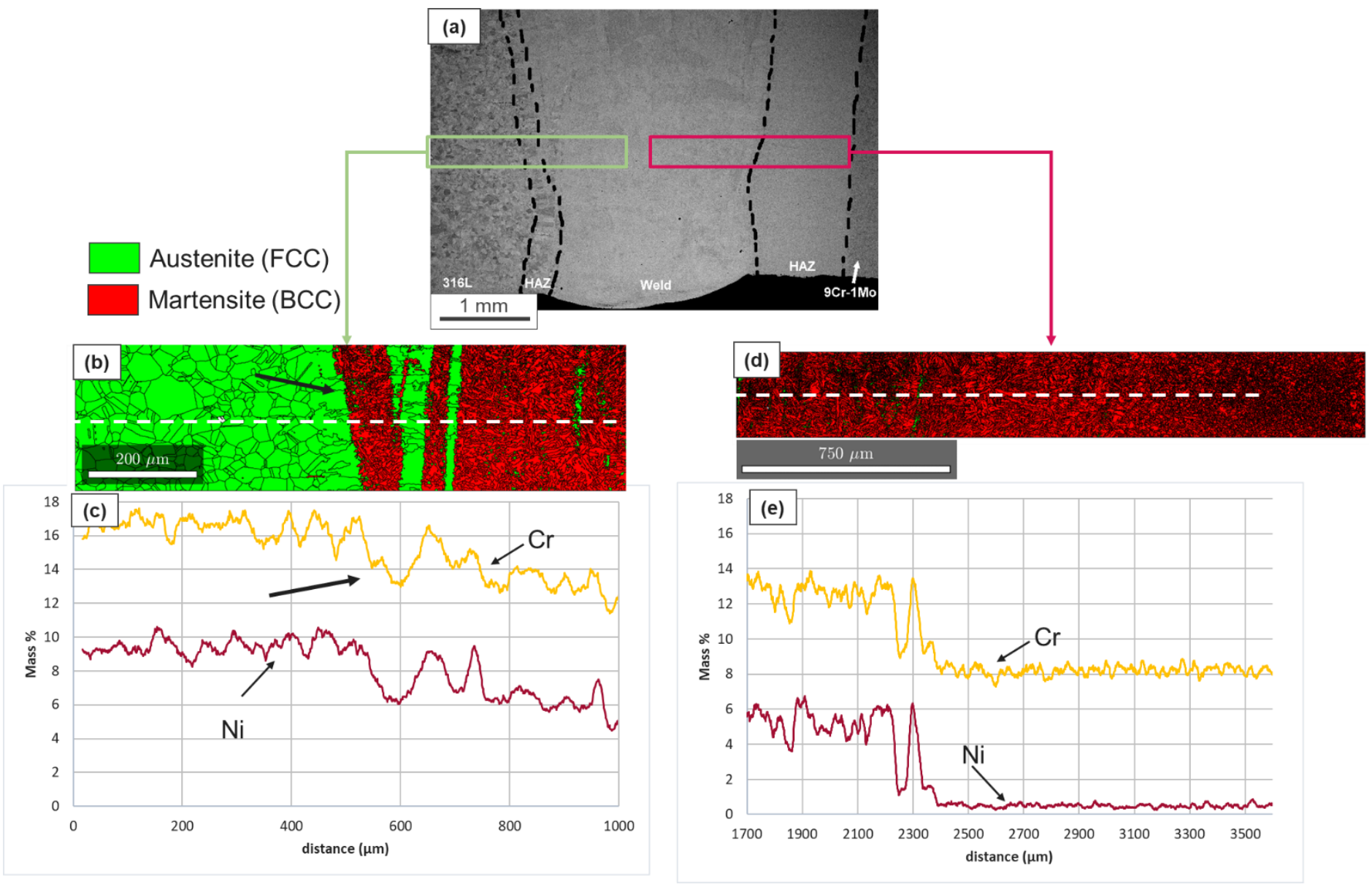

Figure 8: For an EB weld (a) large SEM BSE image, (b) EBSD phase map on 316 side showing martensitic strips (bold arrow), (c) EDS profile along the white dashed line in (b), (d) EBSD phase map on Fe-9Cr-1Mo side and (e) the EDS profile along dashed line. For EBSD maps, 1 pixel $=1.13 \mu \mathrm{m}, 10^{\circ}$ grain boundaries in black. (color figure)

A more precise EBSD phase map of the $316 \mathrm{~L} \mathrm{HAZ}$ is shown in Figure 9. As $316 \mathrm{~L}$ is already austenitic at room temperature only grain growth and formation of delta ferrite islands is observed in the HAZ (Figure 9 (a)). The only major change provoked by the $630^{\circ} \mathrm{C} / 8 \mathrm{~h}$ heat treatment is the reduction of delta ferrite in the HAZ from $~ 2.5 \%$ to $\sim 0.78 \%$ (Figure $9(\mathrm{~b})$ ). 


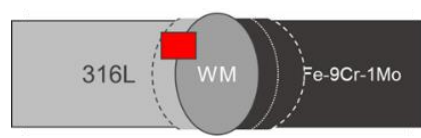

Austenite (FCC)

Martensite (BCC)

\section{(a) As Welded}

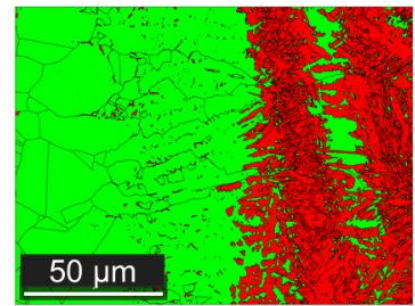

(b) After $630^{\circ} \mathrm{C} / 8 \mathrm{~h}$

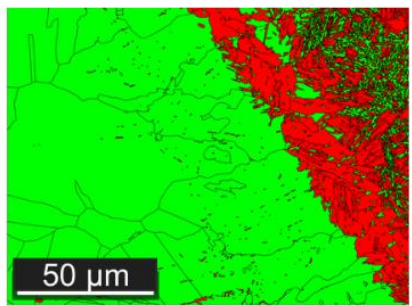

Figure 9: Detail of the 316L HAZ, EBSD phase map (a) as welded and (b) after $630^{\circ} \mathrm{C} / 8 \mathrm{~h}$ heat treatment (1 pixel $=0.1 \mu \mathrm{m}, 10^{\circ}$ grain boundaries in black). (color figure)

The EBSD maps in Figure 10 show the mixed area between austenite and martensite in the weld metal. EBSD observations in this area should interpreted with caution because of the large heterogeneity that can occur due to the welding process. It is interesting to note that, in comparison, the DED-LB graded area seems to be fully martensitic apart from a small two-phase area. For this weld metal composition, the Schaeffler diagram predicts a tri-phased microstructure with austenite, ferrite and martensite. Such microstructure has already been observed by Abburi Venkata et al. [19]. In this area, heat treatment does not affect the very fine lath morphology of martensite. In the weld metal, austenite content seems to increase after heat treatment (Figure 10 (c)), this was also observed in the DED-LB graded area. Such an increase in austenite content due to heat treatment has been reported previously by Liu et al. [20].
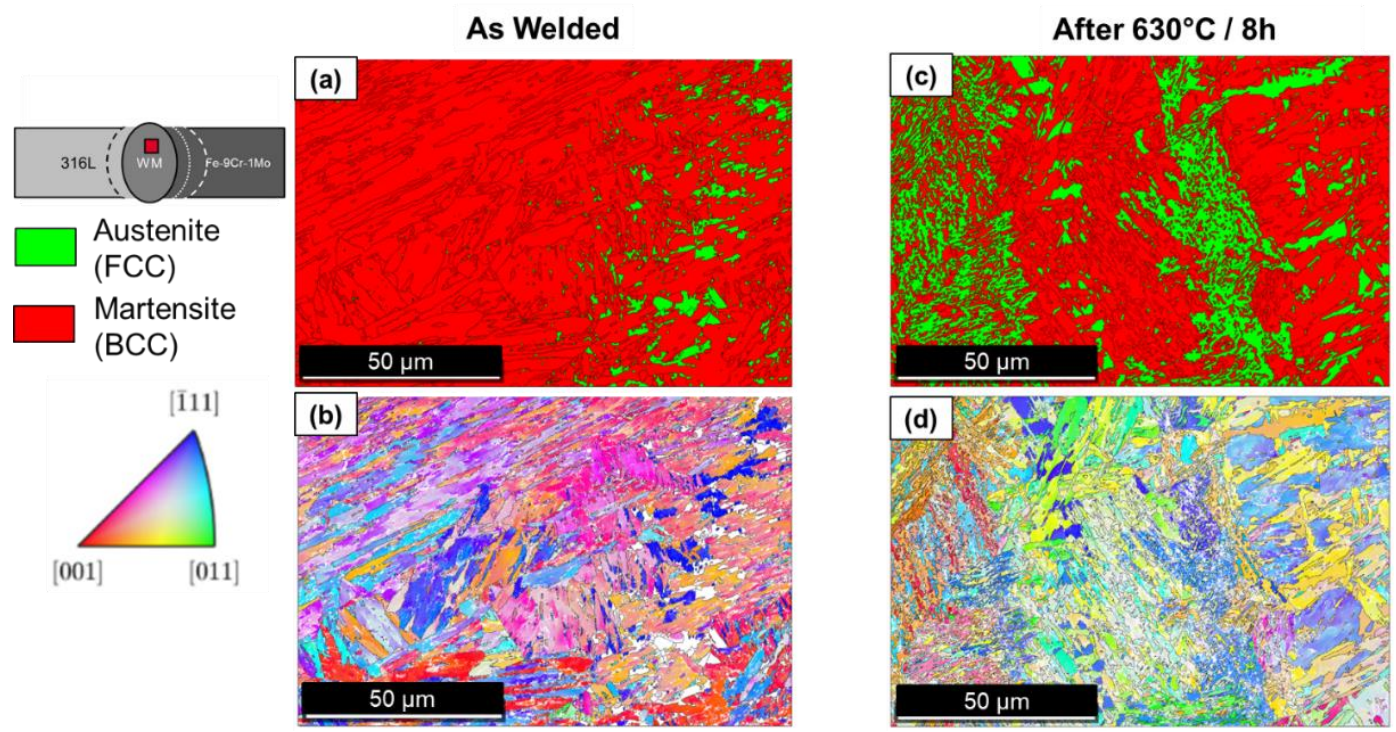

Figure 10: Weld metal in EB welds: (a) phase and (b) IPF EBSD maps as welded and (c) phase and (d) IPF maps after a $630^{\circ} \mathrm{C} / 8 \mathrm{~h}$ heat treatment, emphasizing the formation of austenite in weld metal. ( 1 pixel $=0.1 \mu \mathrm{m}, 10^{\circ}$ grain boundaries in black). (color figure)

Due to the martensite to austenite phase transformation during welding, changes in microstructure occur on the Fe-9Cr-1Mo side. Figure 11 (a) shows a view of the Fe-9Cr-1Mo HAZ after welding. This HAZ can be divided in two areas: a coarse grain HAZ (CGHAZ) near the weld metal and a fine grain HAZ (FGHAZ) further from the weld. Average grain diameters are as follows: $\mathrm{D}(\mathrm{CGHAZ})=14.8 \mu \mathrm{m}, \mathrm{D}(\mathrm{FGHAZ})=$ $6.3 \mu \mathrm{m}$ and $\mathrm{D}(\mathrm{Fe}-9 \mathrm{Cr}-1 \mathrm{Mo} \mathrm{BM})=10.8 \mu \mathrm{m}$. This microstructure is typical of a martensitic HAZ [21]. Heat treatment does not affect the microstructure at this scale and grain sizes are comparable before and after 
heat treatment Figure 11 (b) and (c). The main effect of the heat treatment in this area is decreasing the hardness due to martensite tempering (discussed in the next section).
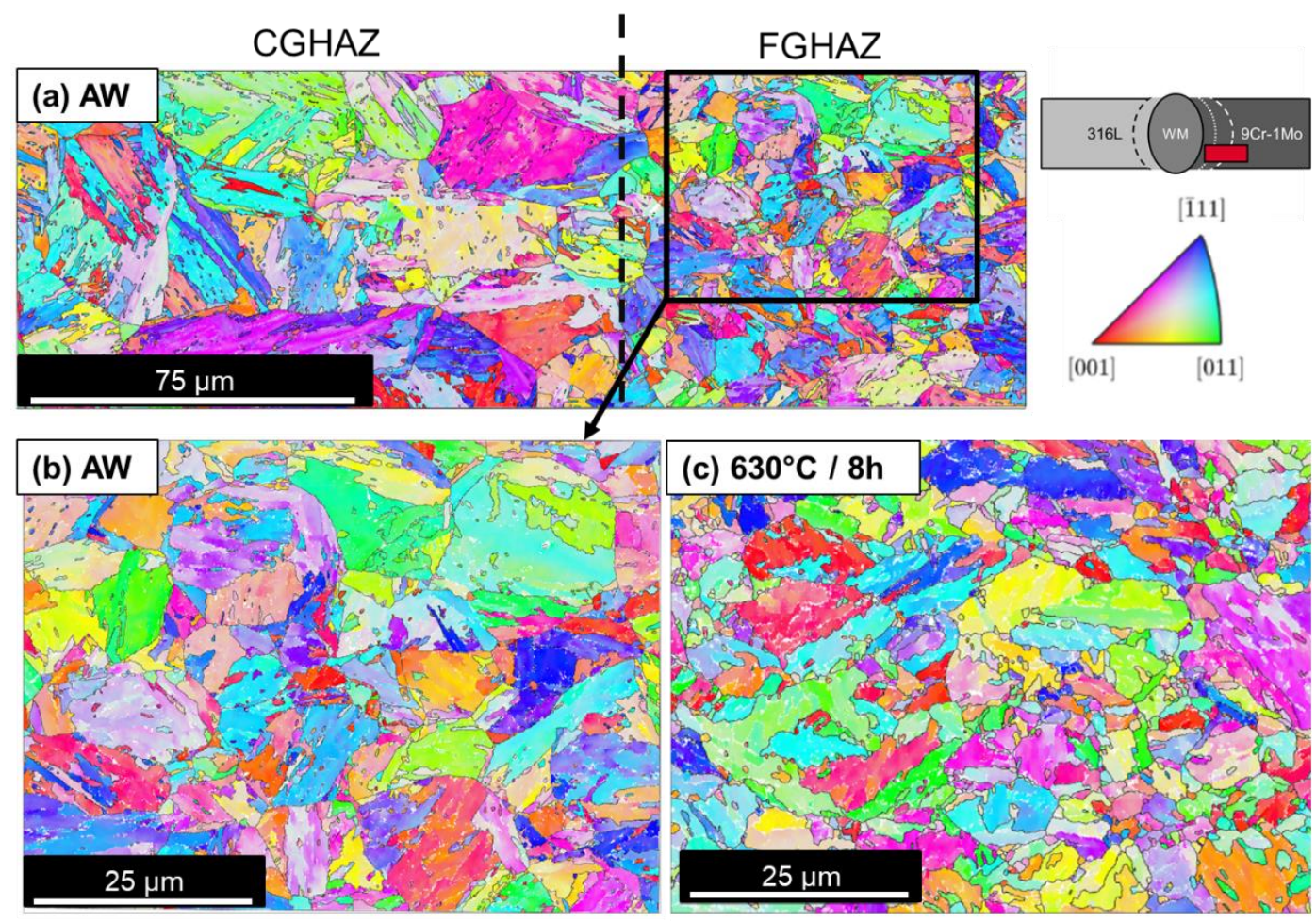

Figure 11: EBSD IPF maps of the Fe-9Cr-1Mo HAZ (1 pixel = $0.1 \mu \mathrm{m})$ : (a) large view of the as welded (AW) Fe-9Cr-1Mo HAZ showing the CGHAZ and the FGHAZ. Detail of the FGHAZ (b) as welded and (c) after $630^{\circ} \mathrm{C} / 8 \mathrm{~h}$ heat treatment. (color figure)

Figure 12 summarizes in schematic form the differences and similarities induced on microstructures by heat treatment on EB welds (Figure 12 (a) and (b)) and DED-LB transitions (Figure 12 (c) and (d)). In DED-LB, delta ferrite was not observed on the $316 \mathrm{~L}$ side unlike in EB welds. Depending on build parameters, for example with a lower energy density, as experienced by Guo et al. [22], it is possible to observe delta ferrite from such a process. The DED-LB mixed area is mainly martensitic with a thin austenitic/martensitic strip. Weld metal is also mainly martensitic with few austenitic areas. At the interface between austenite and martensite some unmixed areas remain both in DED-LB transitions and EB welds. On the Fe-9Cr-1Mo side DED-LB and EB welds are fully martensitic. A smoother chemical gradient is observed in DED-LB samples; as demonstrated by Zuback et al. [23], this can slow down carbon diffusion across the sample and improve ageing resistance. It is also possible to control this gradient in DED-LB by controlling the build parameters.

Applying heat treatment to DED-LB gradients leads to austenite formation in the graded area as it does for EB weld metal (Figure 12). 


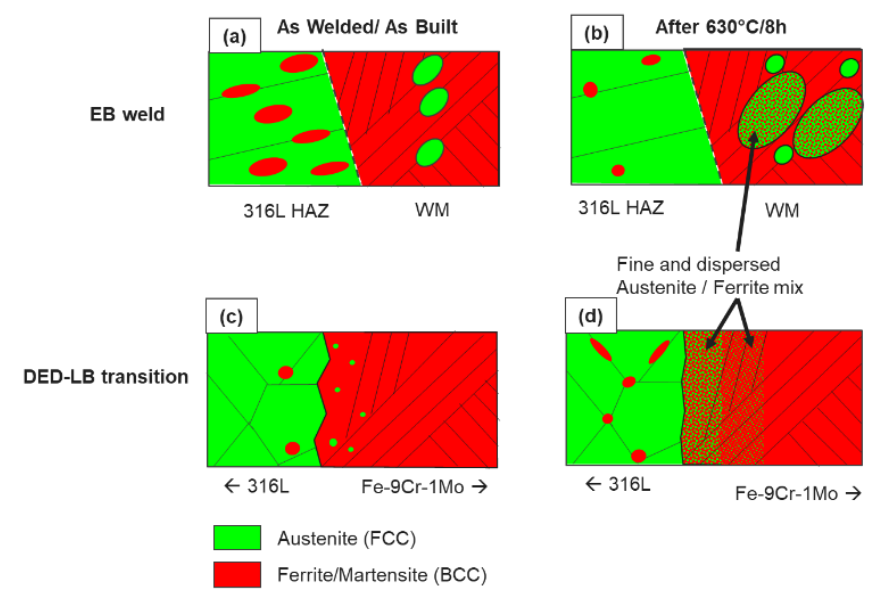

Figure 12: Schematic comparison of microstructure evolution for EB welds (a) before and (b) after $630^{\circ} \mathrm{C} / 8 \mathrm{~h}$ heat treatment and for the DED-LB transition zone (c) before and (d) after heat treatment. (color figure)

\subsection{MeChanical PROPERTIES}

The hardness changes observed in DED-LB gradient materials are also observed in EB welds (Figure 13). EB weld's base material hardnesses are around $150 \mathrm{HV}$ for $316 \mathrm{~L}$ and $230 \mathrm{HV}$ for Fe-9Cr-1Mo (Figure 13 (a)). After welding, weld metal hardness is around $350 \mathrm{HV}$. Soft areas in weld metal correspond to austenitic areas. The higher hardness values (around $400 \mathrm{HV}$ ) are reached in the Fe-9Cr-1Mo HAZ due to formation of fresh martensite in the HAZ during welding. Such hardness variations are the usual observations for austenitic/martensitic dissimilar welds, it is for example observed by Albert et al. [12]. After heat treatment (Figure 13 (b)) hardness in the Fe-9Cr-1Mo HAZ and in the weld metal is reduced due to martensite tempering. As in the DED-LB graded area, weld metal hardness remains above $300 \mathrm{HV}$ after heat treatment but with some soft austenitic areas. 

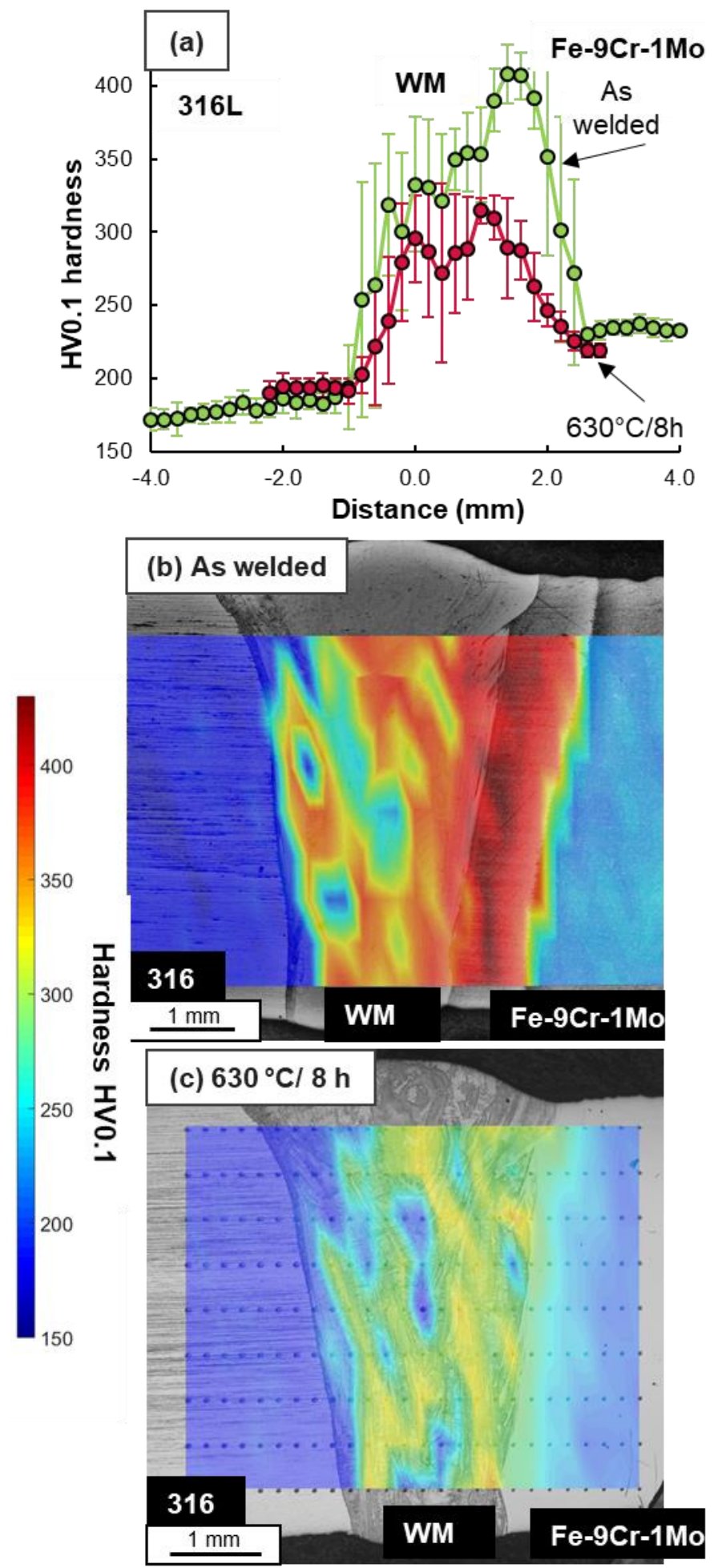

Figure 13: Microhardness maps for EB welds (a) before heat treatment and (b) after $630^{\circ} \mathrm{C} / 8 \mathrm{~h}$ heat treatment. 316L is on left side of the maps shown. (color figure) 


\section{CONCLUSION}

This paper characterizes a DED-LB junction between 316L and Fe-9Cr-1Mo steels and compares results obtained with those from EB welds.

Comparison of EDS profiles obtained across DED-LB junctions and EB welds reveal composition changes with DED-LB can be more gradual than in EB welds. Furthermore, it is possible to control the width of the graded area in DED-LB.

Microstructural study before heat treatment reveals that the DED-LB 316L side is fully austenitic whereas the weld's $316 \mathrm{~L}$ base metal contains few percent of delta ferrite. Some unmixed areas resulting in austenitic and martensitic strips are observed in EB welds at the interface between $316 \mathrm{~L}$ and the weld metal. Such unmixed strips are also observed in DED-LB junctions.

Weld metal and mixed areas are mainly martensitic. Weld metal in EB welds contains few austenitic areas in contrast to the thin area at the austenitic/martensitic transition of DED-LB graded samples. In DED-LB graded area, the microstructure changes suddenly from austenite to martensite. This result highlights the composition at which Ms becomes lower than room temperature because of the composition change. Besides, even if the change of microstructure is not very gradual, such chemically graded part could be interesting because its gradual change in chemistry is able to slow down element's diffusion during thermal ageing [7].

DED-LB Fe-9Cr-1Mo is fully martensitic with a uniform microstructure both close to and far from the gradient area. In EB welds Fe-9Cr-1Mo, microstructure is divided into three regions, depending on the distance from the weld: the CGHAZ close to the weld, the FGHAZ and the base metal which is not affected by the welding process.

Microhardness maps reveal $316 \mathrm{~L}$ and $\mathrm{Fe}-9 \mathrm{Cr}-1$ Mo values far from the junction to be harder in DED-LB materials than in heat treated and laminated plates used for EB welds. Hardness of EB weld metal attains values of $350 \mathrm{HV}$, with the highest hardness values in the Fe-9Cr-1Mo HAZ. Weld metal contains some softer areas which are austenitic. By contrast, hardness in the DED-LB graded area can reach $430 \mathrm{HV}$.

Hardness in EB weld metal and Fe-9Cr-1Mo HAZ is reduced after heat treatment, as it is for the DED-LB mixed area and for the Fe-9Cr-1Mo side. SEM microstructure analysis shows a decrease in the amount of delta ferrite formed on the $316 \mathrm{~L}$ side in $\mathrm{EB}$ welds and formation of austenite islands in the martensitic microstructure in the EB weld metal and DED-LB graded area following heat treatment.

Tensile tests show it is possible to obtain mechanical properties from DED-LB comparable to those from EB welding. Samples from both typically exhibit failure in $316 \mathrm{~L}$ base metal at $20^{\circ} \mathrm{C}$ and $400^{\circ} \mathrm{C}$ and failure in $\mathrm{Fe}-9 \mathrm{Cr}-1 \mathrm{Mo}$ base metal at $550^{\circ} \mathrm{C}$.

This study highlights the great interest in DED-LB as a versatile process to induce composition-graded steel with tailored microstructure and local properties in the graded area.

\section{ACKNOWLEDGEMENTS}

Authors would like to thank Patrice Peyre and Thierry Malot (PIMM Laboratory, Arts et Métiers ParisTech) for their expertise and their help in the production of the DED-LB samples used for this study, Danielle Ayrault and Arnaud Courcelle (CEA-Saclay) for their precious advice in carrying out this study and Owen Johnson for his very valuable advice.

\section{DATA AVAILABILITY}

The raw/processed data required to reproduce these findings cannot be shared at this time as the data also forms part of an ongoing study.

\section{BIBLIOGRAPHY}

[1] C. Pandey, M.M. Mahapatra, P. Kumar, N. Saini, Some studies on P91 steel and their weldments, J. Alloys Compd. 743 (2018) 332-364. https://doi.org/10.1016/j.jallcom.2018.01.120. 
[2] M. Sireesha, S.K. Albert, S. Sundaresan, Microstructure and Mechanical Properties of Weld Fusion Zones in Modified 9Cr-1Mo Steel, J. Mater. Eng. Perform. 10 (2001) 320-330. https://doi.org/10.1361/105994901770345033.

[3] G. Casalino, A. Angelastro, P. Perulli, C. Casavola, V. Moramarco, Study on the fiber laser/TIG weldability of AISI 304 and AISI 410 dissimilar weld, J. Manuf. Process. 35 (2018) 216-225. https://doi.org/10.1016/J.JMAPRO.2018.08.005.

[4] Y. Yano, T. Kaito, T. Tanno, S. Ohtsuka, Weldability of dissimilar joint between PNC-FMS and Type 316 steel under electron beam welding, J. Nucl. Sci. Technol. 52 (2015) 568-579. https://doi.org/10.1080/00223131.2014.964789.

[5] N. Sridharan, E. Cakmak, B. Jordan, D. Leonard, W.H. Peter, R.R. Dehoff, D. Gandy, S.S. Babu, Design , Fabrication , and Characterization of Graded Transition Joints, Weld. J. 96 (2017) 295s306s.

[6] W. Woo, D.-K. Kim, E.J. Kingston, V. Luzin, F. Salvemini, M.R. Hill, Effect of interlayers and scanning strategies on through-thickness residual stress distributions in additive manufactured ferritic-austenitic steel structure, Mater. Sci. Eng. A. 744 (2019) 618-629. https://doi.org/10.1016/J.MSEA.2018.12.078.

[7] J.S. Zuback, T.A. Palmer, T. DebRoy, Additive manufacturing of functionally graded transition joints between ferritic and austenitic alloys, J. Alloys Compd. 770 (2019) 995-1003. https://doi.org/10.1016/J.JALLCOM.2018.08.197.

[8] L. Yan, Y. Chen, F. Liou, Additive Manufacturing of Functionally Graded Metallic Materials Using Laser Metal Deposition, Addit. Manuf. 100901. https://doi.org/10.1016/J.ADDMA.2019.100901.

[9] D. Bardel, D. Nelias, V. Robin, T. Pirling, X. Boulnat, M. Perez, Residual stresses induced by electron beam welding in a 6061 aluminium alloy, J. Mater. Process. Technol. 235 (2016) 1-12. https://doi.org/10.1016/J.JMATPROTEC.2016.04.013.

[10] S. Chowdhury, N. Yadaiah, S. Mujaheed Khan, R. Ozah, B. Das, M. Muralidhar, A Perspective Review on Experimental Investigation and Numerical Modeling of Electron Beam Welding Process, Mater. Today Proc. 5 (2018) 4811-4817. https://doi.org/10.1016/J.MATPR.2017.12.055.

[11] M.S. Węglowski, S. Błacha, A. Phillips, Electron beam welding - Techniques and trends - Review, Vacuum. 130 (2016) 72-92. https://doi.org/10.1016/J.VACUUM.2016.05.004.

[12] S.K. Albert, C.R. Das, S. Sam, P. Mastanaiah, M. Patel, A.K. Bhaduri, T. Jayakumar, C.V.S. Murthy, R. Kumar, Mechanical properties of similar and dissimilar weldments of RAFMS and AISI 316L (N) SS prepared by electron beam welding process, Fusion Eng. Des. 89 (2014) 1605-1610. https://doi.org/10.1016/j.fusengdes.2014.04.063.

[13] S. Wu, Y. Shi, G. Zhang, S. Zhang, H. Liao, X. Wang, Z. Qin, Improving impact toughness of heavy section reduced activation ferritic martensitic CLF-1 steel joints with electron beam welding, J. Nucl. Mater. 531 (2020) 152031. https://doi.org/10.1016/J.JNUCMAT.2020.152031.

[14] T. Persenot, G. Martin, R. Dendievel, J.Y. Buffiére, E. Maire, Enhancing the tensile properties of EBM as-built thin parts: Effect of HIP and chemical etching, Mater. Charact. 143 (2018) 82-93. https://doi.org/10.1016/j.matchar.2018.01.035.

[15] F. Villaret, X. Boulnat, P. Aubry, J. Zollinger, D. Fabrègue, Y. de Carlan, Modelling of delta ferrite to austenite phase transformation kinetics in martensitic steels: application to rapid cooling in additive manufacturing, Materialia. [In Press] (2021).

[16] M.R.U. Ahsan, A.N.M. Tanvir, G.J. Seo, B. Bates, W. Hawkins, C. Lee, P.K. Liaw, M. Noakes, A. Nycz, D.B. Kim, Heat-treatment effects on a bimetallic additively-manufactured structure (BAMS) of the low-carbon steel and austenitic-stainless steel, Addit. Manuf. 32 (2020) 101036. https://doi.org/10.1016/j.addma.2020.101036.

[17] M. Ma, Z. Wang, X. Zeng, A comparison on metallurgical behaviors of $316 \mathrm{~L}$ stainless steel by selective laser melting and laser cladding deposition, Mater. Sci. Eng. A. 685 (2017) 265-273. 
https://doi.org/10.1016/j.msea.2016.12.112.

[18] D.-K. Kim, W. Woo, E.-Y. Kim, S.-H. Choi, Microstructure and mechanical characteristics of multilayered materials composed of $316 \mathrm{~L}$ stainless steel and ferritic steel produced by direct energy $\begin{array}{llllll}\text { deposition, } & \text { J. } & \text { Alloys } & \text { Compd. } & 774 & \text { (2019) }\end{array}$ https://doi.org/10.1016/J.JALLCOM.2018.09.390.

[19] K. Abburi Venkata, C.E. Truman, H.E. Coules, A.D. Warren, Applying electron backscattering diffraction to macroscopic residual stress characterisation in a dissimilar weld, J. Mater. Process. Technol. 241 (2017) 54-63. https://doi.org/10.1016/J.JMATPROTEC.2016.11.003.

[20] G.L. Liu, S.W. Yang, W.T. Han, L.J. Zhou, M.Q. Zhang, J.W. Ding, Y. Dong, F.R. Wan, C.J. Shang, R.D.K. Misra, Microstructural evolution of dissimilar welded joints between reduced-activation ferritic-martensitic steel and $316 \mathrm{~L}$ stainless steel during the post weld heat treatment, Mater. Sci. Eng. A. 722 (2018) 182-196. https://doi.org/https://doi.org/10.1016/j.msea.2018.03.035.

[21] C. Pandey, M.M. Mahapatra, P. Kumar, N. Saini, Some studies on P91 steel and their weldments, J. Alloys Compd. 743 (2018) 332-364. https://doi.org/10.1016/J.JALLCOM.2018.01.120.

[22] P. Guo, B. Zou, C. Huang, H. Gao, Study on microstructure, mechanical properties and machinability of efficiently additive manufactured AISI 316L stainless steel by high-power direct laser deposition, J. Mater. Process. Technol. $240 \quad$ (2017) 12-22. https://doi.org/10.1016/j.jmatprotec.2016.09.005.

[23] J.S. Zuback, T.A. Palmer, T. DebRoy, Additive manufacturing of functionally graded transition joints between ferritic and austenitic alloys, J. Alloys Compd. 770 (2019) 995-1003. https://doi.org/10.1016/J.JALLCOM.2018.08.197. 